\title{
DIMENSI SERVICE QUALITY DAN KEPUASAN WAJIB PAJAK PBB DI KABUPATEN MALANG
}

\author{
Harinoto \\ E-mail: natawardhana@gmail.com
}

\begin{abstract}
Abstrak : Tujuan penelitian ini dimaksudkan untuk menganalisis dimensi Service Quality dan kepuasan wajib pajak bumi dan bangunan (PBB) di Kabupaten Malang. Jenis penelitian menjelaskan (explanatory) hubungan kausal dan pengujian hipotesis beberapa variable independen terhadap variable dependen. Hasil analisis penelitian, dimensi service quality secara sendiri sendiri yang terdiri dari bukti langsung, keandalan, daya tanggap dan jaminan memberi pengaruh secara berarti terhadap kepuasan wajib pajak PBB. Sementara variable emphaty, tidak memiliki pengaruh yang nyata bagi kepuasan wajib pajak PBB. Secara bersamasama dimensi service quality memberi pengaruh secara nyata terhadap kepuasan wajib pajak PBB, yang mana nilai $\mathrm{F}_{\text {hitung }}=15.862$ diikuti nilai signifikansi $0,000<0,05$ dan nilai Adjusted R Square 45.20\%, sisanya $54.8 \%$ kepuasan wajib pajak PBB dipengaruhi faktor lain yang tidak diteliti dalam penelitian ini. Faktor yang berpengaruh dominan terhadap kepuasan wajib pajak PBB adalah variabel keandalan dengan meletakkan nilai-nilai pelayanan dengan kemampuan untuk memberikan apa yang telah dijanjikan dengan akurat sesuai standar prosedur operasi, Untuk bahan evaluasi dan instruspeksi, perlu memperhatikan wajib pajak, sehingga terjaga bahkan dapat ditingkatkan. Sedangkan empati yang mengetengahkan kepedulian, keeratan hubungan social dan dukungan terhadap inovasi, saran/ masukan wajib pajak belum memberi kontribusi terhadap kepuasan wajib pajak PBB. Kandisi ini menunjukkan perlu terus diupayakan secara berkelanjutan meningkatkan empati kepada wajib pajak.
\end{abstract}

Kata-kata kunci : Service Quality, Kepuasan wajib pajak, \& DPPKAD Kabupaten Malang

\section{PENDAHULUAN}

Salah satu asset daerah yang besar peranannya di era Otonomi Daerah ini adalah Pajak Bumi dan Bangunan. Pajak ini pada masa lalu di kelola oleh Dirjen Pajak Kementerian Keuangan RI, kemudian dengan Otonomi Daerah ini sekarang diserahkan sepenuhnya kepada Pemerintah Daerah setempat. Sehingga memerlukan infra struktur pendukung dan sumberdaya manusia yang memadahi dalam penerimaan Pajak Bumi dan Bangunan ini. Tidak cukup dengan itu, nampaknya harus disiapkan berbagai hal yang mendukung tercapainya output dan

Harinoto, adalah Dosen Prodi Manajemen Universitas Kanjuruhan Malang 
outcome pajak ini secara optimal sehingga mampu memberikan kontribusi yang nyata terhadap peningkatan pembangunan dan kesejahteraan masyarakat.

Ada langkah-langkah untuk belajar banyak tentang pelayanan dan penerimaan Pajak Bumi Bangunan ini. Agar semakin berdaya guna dan berhasil guna dalam mendukung pembangunan di Daerah. Sehingga sangat perlu dilakukan verifikasi pekerjaan dan tempat kerja yang memadahi, dalam mendukung pelayanan prima, yang didukung oleh seperangkat teknologi informatika serta manusianya yang kompeten sehingga memberikan kepuasan kepada pelanggan wajib pajak. Era sekarang dengan berbagai tuntutan masyarakat terus berbenah dan meningkatkan, seperti pelayanan air bersih, listrik, sarana angkutan, makanan cepat saji dan tempat hiburan. Kondisi ini sesuai dengan kecenderungan masyarakat bahwa kebutuhan terhadap ragam dan mutu jasa akan selaras dengan perkembangan kualitas hidup dan pendapatan masyarakat tersebut.

Persoalannya tidak mudah seperti membalik tangan, perlu proses dan pembelajaran yang terus menerus. Demikian juga kantor pelayanan seperti PBB yang baru diserahkan kepada Pemerintah Daerah harus berkomitmen untuk berbenah, meningkatkan kepuasan wajib pajak, peningkatan pendapatan, sekaligus memaksimumkan pelayanan wajib pajak dan mengeliminir segala sesuatu yang kurang memuaskan wajib pajak. Kualitas pelayanan (service quality) harus diawali dari kebutuhan wajib pajak dan berakhir dengan persepsi wajib pajak. Citra kualitas yang baik bukanlah berdasarkan pada persepsi kantor pelayanan, akan tetapi berdasarkan persepsi dari wajib pajak. Sebagaimana Tjiptono, (2005) menyebutkan bahwa tujuan sebuah bisnis adalah menciptakan para wajib pajak yang puas. Di satu sisi, meyakini bahwa peningkatan pendapatan menimbulkan kualitas jasa. Peningkatan pendapatan terhadap pelayanan jasa akan mengarah pada sikap keseluruhan terhadap kualitas jasa sepanjang waktu .

Kantor yang representative, diikuti dengan ruang tunggu yang nyaman, pegawai front line yang ramah, murah senyum, serta pelayanan yang akurat dan cepat. Oleh karena itu setiap kantor pelayanan berusaha meningkatkan kualitasnya dalam berbagai segi yang berimplikasi pada kepuasan wajib pajak dan ujungnya peningkatan pendapatan $\mathrm{PBB}$, karena itu pemerintah pusat pemberikan kewenangan kepada daerah untuk mengelola PBB yang tersedia diwilayahnya dalam rangka mempercepat pelayanan, mempercepat kesejahteraan serta pendapatan daerah untuk proses pembangunan daerah yang lebih baik dan maju. Dari pola pikir tersebut, maka muncul pertanyaan apakah kualitas pelayanan dapat meningkatkan kepuasan wajib pajak PBB di Kabupaten Malang.

\section{TINJAUAN PUSTAKA}

\section{Dimensi Service Quality}

Hartono \& Gregorius Chandra, (2005) pelayanan berarti menyediakan segala apa yang diperlukan orang lain. Selanjutnya Zeithalm \& Bitner, (2002) mengemukakan :"Put in the most simple terms, services are deeds, processes, and performances. But for the most part, the entire service is represented to the client through problem analysis activities, meeting with the client follow-up calls, and reporting a series of deeds, processes, and performance. Similary, the core 
offering of hospitals, hotels, banks, and utilities comprise primarily deeds and fictions performed for customer".

Kualitas jasa adalah tingkat keunggulan yang diharapkan serta pengendalian atas tingkat keunggulan tersebut untuk memenuhi keinginan pelanggan". Dengan kata lain ada dua faktor utama yang mempengaruhi kualitas pelayanan (service quality), yaitu expected service dan perceived service. Model Kualitas pelayanan secara konseptual sebagai berikut :

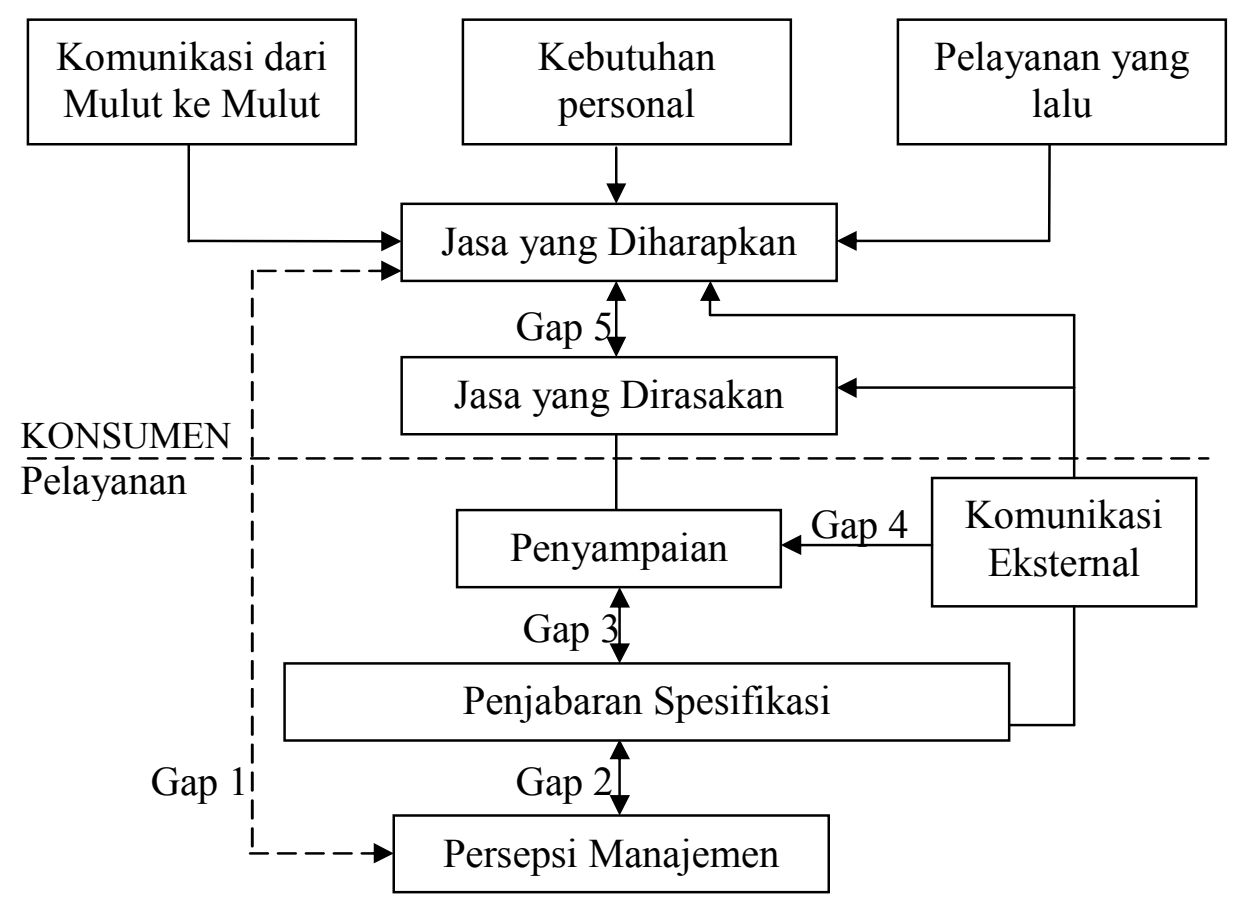

Gambar 1. Model Kualitas Pelayanan, (Parasuraman, Valarie, \& Leonard L, 1988)

Model ini mengidentifikasi lima gap yang menyebabkan kegagalan penyampaian jasa, yaitu gap antara harapan wajib pajak dan persepsi manajemen., yaitu tidak selalu dapat merasakan atau memahami apa yang diinginkan wajib pajak secara tepat. Akibatnya manajemen tidak mengetahui bagaimana suatu jasa seharusnya didesain, dan jasa-jasa pendukung/sekunder apa saja yang diinginkan wajib pajak. Kedua gap antara persepsi manajemen terhadap harapan wajib pajak, kadang tidak menyusun suatu standar kinerja tertentu yang jelas. Hal ini bisa dikarenakan tiga faktor yaitu tidak adanya komitmen total manajemen terhadap kualitas jasa, kekurangan sumberdaya atau karena adanya kelebihan permintaan. Ketiga, gap antara spesifikasi kualitas jasa dan penyampaian jasa, misalnya karyawan kurang terlatih (belum menguasai tugasnya), beban kerja melampaui batas, tidak dapat memenuhi standar kinerja, atau bahkan tidak mau memenuhi standar kinerja yang ditetapkan. Keempat, gap antara penyampaian jasa dan komunikasi eksternal, yaitu seringkali harapan wajib pajak dipengaruhi oleh iklan dan pernyataan atau janji yang dibuat oleh kantor pelayanan. Risikonya adalah 
apabila janji yang diberikan ternyata tidak dapat dipenuhi maka akan menimbulkan masalah baru, Kelima gap antara jasa yang dirasakan dan jasa yang diharapkan, bila wajib pajak mengukur kinerja/prestasi kantor pelayanan dengan cara yang berlainan, atau bisa juga keliru mempersepsikan kualitas jasa tersebut.

Mengenal dimensi kualitas pelayanan (service quality), Parasuraman menyatakan pelayanan yang ada di masyarakat harus memenuhi sepuluh dimensi yang diusulkan berdasarkan hasil penelitiannya, yaitu: Tangibles, Reliability, Responsiveness, Communication, Credibility, Security, Competence, Courtesy, Understanding/knowing and Access. Dalam perkembangan selanjutnya tahun 2008, Parasuraman merangkum menjadi lima dimensi pokok, meliputi bukti Langsung atau Tangibles, meliputi fasilitas fisik, perlengkapan, pegawai dan sarana komunikasi, keandalan atau Reliability, yakni kemampuan memberikan pelayanan yang dijanjikan dengan segera, akurat dan memuaskan, daya tanggap atau Responsiveness, yaitu keinginan para staf untuk membantu para wajib pajak dalam memberikan pelayanan dengan tanggap. Jaminan atau Assurance, mencakup pengetahuan, kemampuan, kesopanan, dan sifat dapat dipercaya yang dimiliki para staf, bebas dari bahaya, resiko atau keragu-raguan. Emphaty, meliputi kemudahan dalam melakukan hubungan, komunikasi yang baik, perhatian pribadi dan memahami kebutuhan para pelanggan. Model pengukuran Parasuraman et al., (1988) telah dibuat sebuah skala multi item yang diberi nama SERVQUAL. Alat ini dimaksudkan untuk mengukur harapan dan persepsi wajib pajak (gap) yang ada di model kualitas pelayanan.

Pujiastuti, (2009) penelitiannya tentang Kualitas Layanan dan Kepuasan pelanggan (Service quality) di Bank Bank di Kota Malang. Hasilnya bahwa terdapat pengaruh yang signifikan bukti langsung, keandalan, daya tanggap, jaminan, dan empati terhadap tingkat kepuasan pelanggan. Dari kelima variabel bebas yang mempunyai pengaruh dominan adalah variabel daya tanggap. Priambodo, (2009) penelitiannya dengan topik serupa di Dinas Pendapatan Pengelolaan Keuangan dan Asset Daerah di Kabupaten Ponorogo. Hasil-nya 5 dimensi Kualitas pelayanan dengan instrument SERVQUAL, terdapat satu dimensi Kualitas pelayanan yang paling dipertimbangkan wajib pajak serta mempunyai pengaruh dominan terhadap Kepuasan pelanggan yaitu Empati

Tribus \& Klassen, (2000), penelitiannya tentang Service Quality: A Study of Parking Satisfaction at A University in California State University Northridge $(C S U N)$, dengan membandingkan antara harapan dengan persepsi. diambil 159 orang responden (86 orang laki-laki dan 73 orang perempuan) dengan menggunakan 159 kuisioner dengan 75 pertanyaan pokok. Hasilnya menunjukkan bahwa pengukuran Kualitas pelayanan adalah tantangan tetapi juga merupakan kebutuhan untuk mengidentifikasi perbaikan kepuasan pelanggan. Siu \& Cheung, (2001), meneliti Measure of Retail Service Quality, dengan sektor perdagangan eceran, dengan enam dimensi, yaitu interaksi personal, kebijakan, wujud fisik, kepercayaan, pemecahan masalah dan ketepatan. Hasilnya wujud fisik dan kebijakan merupakan hal yang sangat dominan dari keseluruhan dimensi kualitas pelayanan yang diteliti serta mempengaruhi kebiasaan belanja para konsumen di masa yang akan datang.

Dari beberapa penelitian diatas, topik yang sama dengan sudut pandang dan obyek yang berbeda hasilnya berbeda-beda. Implikasinya penelitian ini masih debatable, 
lebih lanjut dimensi penelitian ini memerlukan dinamika perubahan. Sehingga persoalan ini masih menarik untuk diteliti dan dikembangkan. Berdasarkan kajian empiris ini, maka hipotesis penelitian ini adalah :

H1. Jika dimensi service quality yang terdiri bukti langsung/ tangibles $\left(\mathrm{X}_{1}\right)$, keandalan/ reliability $\left(\mathrm{X}_{2}\right)$, daya tanggap/ responsiveness $\left(\mathrm{X}_{3}\right)$, jaminan/ assurance $\left(\mathrm{X}_{4}\right)$ dan empati/ empathy $\left(\mathrm{X}_{5}\right)$ di tingkatkan, maka secara parsial berpengaruh terhadap kepuasan wajib pajak PBB (Y).

H2. Jika dimensi service quality secara serempak ditingkatkan, maka akan berpengaruh kuat terhadap kepuasan wajib pajak $(\mathrm{Y})$.

Disusun kerangka konsep penelitian, seperti gambar dibawah ini :

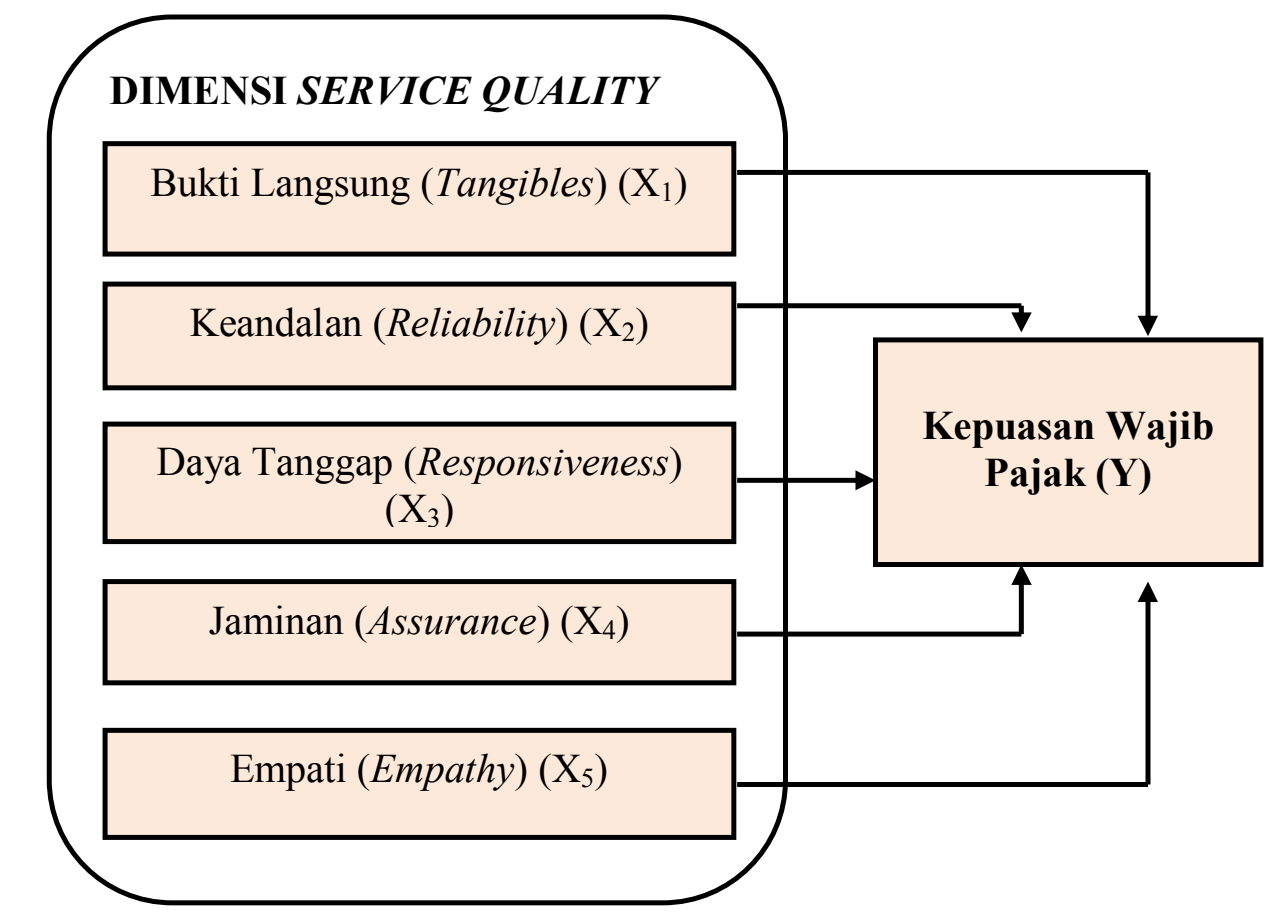

Gambar 1. Kerangka Konsep Penelitian

\section{METODE}

Penelitian ini termasuk penelitian kuantitatif, dengan responden adalah wajib pajak yang datang membayar PBB di Kantor pelayanan PBB Dinas Pendapatan Pengelolaan Keuangan dan Asset Daerah dengan menyebut asal wilayah untuk satu bulan terakhir, bulan Nopember yang diambil rata-rata berjumlah : 1005 orang. Kemudian untuk menentukan ukuran sampel (banyaknya responden) digunakan rumus Yamane, dalam (Singarimbun \& Effendi, 2005) yaitu : 


$$
n=\frac{1005}{1005(0,1)^{2}+1}=\frac{1005}{11,05}=90.95=91
$$

Teknik pengambilan sampel dengan metode insidental random sampling dimana unit dari populasi diberi nomor antrian. Selanjutnya dari anggota yang ingin dipilih ditentukan secara insidental, wajib pajak datang ke Kantor pelayanan PBB untuk membayar Pajak PBB. Selanjutnya analisis data menggunakan rumus regresi yaitu:

$\mathrm{Y}=\mathrm{b}_{0}+\mathrm{b}_{1} \mathrm{X}_{1}+\mathrm{b}_{2} \mathrm{X}_{2}+\ldots \ldots \ldots \ldots+\mathrm{b}_{\mathrm{k}} \mathrm{X}_{\mathrm{k}}+\mathrm{e}$

Melalui analisis tersebut, dilakukan uji hipotesis untuk membuktikan kebenaran secara ilmiah.

\section{PEMBAHASAN}

Hasil analisis deskriptif melalui uji distribusi frekuensi dan rata-rata jawaban responden, dimensi kualitas pelayanan dapat digambarkan bahwa: a. Kondisi bukti langsung tempat pelayanan mengambarkan kondisi yang prima, toilet yang bersih, ruang tunggu yang nyaman, walaupun ada persoalan yang kurang mendukung terkait sikap dan perilaku petugas yang kadang-kadang tidak ramah, b. Keandalan pelayanan dirasakan memenuhi equity walaupun kadangkadang masih terjadi error, c. Daya tanggap terhadap keluhan wajib pajak kategori bagus, walaupun kadang kadang kurang efisien, d. Jaminan memiliki reputasi terpercaya walaupun ada persoalan oknum yang kurang jujur, e. Empati terhadap masukan, saran dan kritik menjadi perhatian manajemen walaupun harus terus dilakukan inovasi inovasi yang urgen, sehingga dimensi - dimensi tersebut dapat meningkatkan kepuasan wajib pajak bumi dan bangunan

Hasil uji regresi linier berganda, untuk mengetahui koefisien regresi (b) masing-masing variabel bebas kontribusinya terhadap kepuasan wajib pajak PBB. dapat ditampikan matrik sebagai berikut :

Tabel 1. Hasil analisis regresi linier berganda

\begin{tabular}{|c|l|c|c|c|c|}
\hline No & \multicolumn{1}{|c|}{ Variabel } & $\begin{array}{c}\text { Koefisien } \\
\text { regresi (b) }\end{array}$ & t hitung & Signifikansi & Keterangan \\
\hline 1 & $\begin{array}{l}\text { Bukti langsung } \\
\text { X1) }\end{array}$ & 0.157 & 2.665 & 0.009 & Ho ditolak \\
\hline 2 & Keandalan (X2) & 0.410 & 3.031 & 0.003 & Ho ditolak \\
\hline 3 & Daya tanggap (X3) & 0.262 & 2.763 & 0.007 & Ho ditolak \\
\hline 4 & Jaminan (X4) & 0.204 & 2.245 & 0.027 & Ho ditolak \\
\hline 5 & Empati (X5) & -0.176 & -1.594 & 0.115 & Ho diterima \\
\hline 6 & Konstanta $\left(\beta_{0}\right)$ & 3.391 & & \\
\hline R Square (R $\left.{ }^{2}\right)$ & $=0.695$ \\
\hline \multicolumn{2}{|l|}{ Multiple R } & $=0.483$ \\
\hline \multicolumn{2}{|l|}{ Adjusted R Square } & $=0.452$ \\
\hline
\end{tabular}




\begin{tabular}{|l|l|}
\hline $\mathrm{F}$ table & $=4.1055$ \\
\hline $\mathrm{t}$ table & $=1.6751$ \\
\hline$\alpha$ & $=5 \%$ \\
\hline
\end{tabular}

Sumber: Data Primer Diolah, 2015

Berdasarkan hasil analisis regresi tersebut, maka regresinya sebagai berikut :

$$
\mathrm{Y}=3.391+0.157 \mathrm{X} 1+0.410 \mathrm{X} 2+0.262 \mathrm{X} 3+0.204 \mathrm{X} 4-0.176 \mathrm{X} 5+\mathrm{e}
$$

1. $\mathrm{a}=3.391$ : merupakan nilai konstanta yang menunjukkan bahwa apabila tidak ada lima dimensi kualitas pelayanan tersebut, maka kepuasan wajib pajak PBB akan berada pada posisi tetap 3.391

2. $\mathrm{b}_{1}=0.157 \mathrm{X}_{1}$ : koefisien bukti langsung, yang meliputi kelengkapan hardware dan software, sikap dan penampilan karyawan, produk, yang mencerminkan tentang keadaan fisik dan keadaan piranti, maka meningkatkan kepuasan wajib PBB. Jika bukti langsung meningkat $1 \%$, maka kepuasan wajib pajak PBB meningkat sebesar $15.70 \%$.

3. $\mathrm{b}_{2}=0.410 \mathrm{X}_{2}$ : koefisien keandalan karyawan yang meliputi kemampuan untuk memberikan apa yang telah dijanjikan dengan akurat sesuai standar prosedur operasi, yang meliputi ketepatan pelayanan, keadilan pelayanan, kesalahan minimal pelayanan, dan keandalan pelayanan, maka kepuasan wajib pajak PBB akan meningkat. Jika Keandalan karyawan meningkat 1\%, maka kepuasan wajib pajak PBB akan meningkat sebesar $41.0 \%$.

4. $\mathrm{b}_{3}=0.262 \mathrm{X}_{3}$ : koefisien daya tanggap, akan meningkatkan pendapatan PBB. Jika daya tanggap meningkat 1\%, maka pendapatan PBB juga akan meningkat sebesar $26.20 \%$.

5. $\mathrm{b}_{4}=0.204 \mathrm{X}_{4}$ : koefisien jaminan, meningkatkan kepuasan wajib pajak PBB. Jika ada kepercayaan dan keyakinan, adanya moral dan kejujuran, pengetahuan karyawan, reputasi yang baik, maka kepuasan wajib pajak PBB juga meningkat. Jika jaminan meningkat $1 \%$, maka kepuasan wajib pajak PBB di Kabupaten Malang juga akan meningkat sebesar 20.40\%.

6. $\mathrm{b}_{5}=-0.176 \mathrm{X}_{5}$ : koefisien peran empati, maka meningkatan kepuasan wajib pajak PBB. Jika rasa peduli kepada wajib pajak tinggi, maka kepuasan wajib pajak PBB akan meningkat. Kondisinya daya empati berbanding terbalik dengan kepuasan wajib pajak PBB sebesar $17.60 \%$.

Koefisien determinasi 0.452 berarti dimensi kualitas pelayanan berupa bukti langsung, keandalan, daya tanggap, jaminan dan empati memberikan kontribusi terhadap kepuasan wajib pajak PBB sebesar $45.20 \%$, sisanya $54.80 \%$ dipengaruhi oleh dimensi lain yang tidak diteliti atau di luar model penelitian ini. Asumsi peneliti dapat memprediksikan bahwa disamping dimensi-dimensi tersebut yang mempengaruhi kepuasan wajib pajak PBB, dapat pula dimensi iklim dan suasana kerja, leadershifnya mempengaruhi kepuasan wajib pajak, dst. Hasil $\mathrm{F}_{\text {hitung }}$ sebesar $15.862>\mathrm{F}_{\text {tabel }}$ pada taraf nyata $\alpha=0,05$ sebesar 4.1055. Hal ini sesuai dengan kriteria yang ditetapkan. Ditolaknya Ho dan diterima Ha berarti variabel bebas mempunyai pengaruh yang positif atau bermakna (significant) terhadap variabel terikat, dapat diterima atau terbukti. 
Untuk uji hipotesis masing masing dimensi kualitas pelayanan dijelaskan sebagai berikut

a. Bukti langsung, nilai $t_{\text {hitung }}=2.665$ dengan $t_{\text {tabel }}=1.6751\left(t_{\text {hitung }}>t_{\text {tabel }}\right)$, yang didukung oleh nilai sign $0.009<0.05$ maka Ho ditolak dan Ha diterima. Hal ini berarti ada pengaruh signifikan antara Bukti langsung terhadap kepuasan wajib pajak PBB.

b. Keandalan, nilai $t_{\text {hitung }}=3.031$ dengan $t_{\text {tabel }}=1.6751\left(t_{\text {hitung }}>t_{\text {tabel }}\right)$, yang didukung oleh nilai sign $0.003<0.05$ maka Ho ditolak dan Ha diterima. Hal ini berarti ada pengaruh signifikan antara Keandalan terhadap kepuasan wajib pajak PBB.

c. Daya tanggap, nilai $t_{\text {hitung }}=2.763$ dengan $t_{\text {tabel }}=1.6751\left(t_{\text {hitung }}>t_{\text {tabel }}\right)$, yang didukung oleh nilai sign $0.007<0.05$ maka Ho ditolak dan Ha diterima. Hal ini berarti ada pengaruh signifikan antara daya tanggap terhadap kepuasan wajib pajak $\mathrm{PBB}$.

d. Jaminan, nilai $t_{\text {hitung }}=2.245$ dengan $t_{\text {tabel }}=1.6751\left(t_{\text {hitung }}>t_{\text {tabel }}\right)$, yang didukung oleh nilai sign $0.027<0.05$ maka Ho ditolak dan Ha diterima. Hal ini berarti ada pengaruh signifikan antara jaminan terhadap kepuasan wajib pajak PBB.

e. Empati , nilai $t_{\text {hitung }}=-1.594$ dengan $\mathrm{t}_{\text {tabel }}=1.6751\left(\mathrm{t}_{\text {hitung }}<\mathrm{t}_{\text {tabel }}\right)$, yang didukung oleh nilai sign $0.115>0.05$ maka Ho diterima dan Ha ditolak. Hal ini berarti tidak ada pengaruh signifikan antara empati terhadap kepuasan wajib pajak PBB.

Sehingga dari lima dimensi, ada 4 dimensi yang memiliki pengaruh terhadap kepuasan wajib pajak PBB, yaitu bukti langsung, keandalan, daya tanggap dan jaminan. Posisi yang dominan mempengaruhi kepuasan wajib pajak PBB adalah keandalan.

Berdaasarkan hasil penelitian ini maka secara umum kualitas pelayanan telah memberikan kontribusi terhadap kepuasan wajib pajak PBB. Jika bukti langsung, keandalan, daya tanggap, jaminan dan empati secara konsisten dilaksanakan dengan baik maka bisa dipastikan akan dapat meningkatkan kepuasan wajib pajak PBB. Hal ini sesuai dengan Hartono bahwa pelayanan berarti menyediakan segala apa yang diperlukan orang lain. Ada dua faktor utama yang mempengaruhi dimensi service quality yaitu expected service dan perceived service. Intern organisasi dan lingkungan ekstern, memberikan andil terhadap kepuasan wajib pajak PBB, karena itu harus ada upaya mendorong karyawan untuk bersikap kreatif dan inovasi, menghargai tindakan berani mengambil resiko dalam melaksanakan tugas guna peningkatan kepuasan wajib pajak PBB. Organisasi mempunyai trik/ cara/ strategi tertentu untuk mempertahankan pelayanan yang prima secara konsekuen kepada wajib pajak.

Organisasi telah memulainya, untuk menanamkan nilai-nilai kepada para karyawan sebagai service front line. Organisasi lebih memusatkan perhatian pada hasil yang dikerjakan, melakukan evaluasi secara berkala, selalu berusaha memberi solusi terbaik bagi persoalan, memperhitungkan dampak perilaku orang-orang di dalam organisasi dan mendorong karyawan untuk melaksanakan ide-ide kreatif serta memberikan apresiasi kepada karyawan yang berhasil dalam menjalankan tugasnya. Organisasi juga memperhatikan pekerjaan berdasarkan kelompok/tim, memberi penghargaan kepada unit kerja tertentu yang berhasil memenuhi target 
kerja organisasi, memberi kesempatan melaksanakan program kerja secara inovatif, mendorong setiap karyawan agar disiplin untuk menjalankan pekerjaan dan mendorong karyawan untuk mencapai hasil kerja yang optimal. Karenanya ia berperan penting mengarahkan tindakan yang ada dalam organisasi untuk mencapai tujuan organisasi.

Dinas Pendapatan Pengelolaan Keuangan dan Asset Daerah Kabupaten Malang, sebagai salah satu andalan perubahan di era otonomi daerah, harus menunjukkan sebagai organisasi yang profesional dan dipercaya masyarakat luas. Karenanya paradigma pengembangan organisasi sudah saatnya diubah, yaitu bertumpu pada kekuatan bersama. Karyawan sebagai ujung pelayanan front line harus dilibatkan dalam proses mencari ide, gagasan dan saran pengembangan organisasi meskipun keputusan akhir tetap berada pada Kepala Dinas. Sehingga menumbuhkan loyalitas dan partisipasi karyawan untuk meningkatkan rasa memiliki dan kepeduliannya terhadap organisasi.

\section{KESIMPULAN DAN SARAN}

\section{Kesimpulan}

1. Secara sendiri-sendiri dimensi service quality yang terdiri dari bukti langsung, keandalan, daya tanggap dan jaminan memberi pengaruh terhadap kepuasan wajib pajak PBB di Dinas PPKAD Kabupaten Malang. Sementara variable emphaty, belum memiliki pengaruh yang nyata bagi kepuasan wajib pajak $\mathrm{PBB}$

2. Secara bersama-sama dimensi service quality memberi pengaruh secara nyata terhadap kepauasan wajib PBB di Dinas PPKAD Kabupaten Malang. Kontribusinya $54.80 \%$ terhadap kepuasan wajib pajak , sisanya berarti dipengaruhi oleh dimensi lain seperti iklim dan suasana kerja, leadershif nya

3. Dimensi yang berpengaruh dominan terhadap kepuasan wajib pajak PBB adalah variabel Keandalan/reliability dengan meletakkan nilai-nilai pelayanan yang berkaitan dengan kemampuan untuk memberikan apa yang telah dijanjikan dengan akurat sesuai standar prosedur operasional.

\section{Saran}

Disarankan kepada peneliti berikutnya, yang hendak mengkaji masalah kepuasan wajib pajak PBB memasukkan dimensi lain yang secara teoritis berpengaruh pada kepuasan wajib pajak PBB tersebut.

Bagi kepala Dinas disampaikan bahwa Keandalan/reliability mendapat perhatian yang baik oleh masyarakat wajib pajak, sehingga perlu apresiasi bagi karyawan yang memenuhi keandalan, sedangkan dimensi empati perlu upaya lebih ekstra untuk melakukan perubahan paradigma pelayanan lebih progresif supaya dapat mendukung peningkatan pelayanan dimensi lainnya sehingga dapat meningkatkan kepuasan wajib pajak secara baik. 
176 MODERNISASI, Volume 11, Nomor 3, Oktober 2015

\section{DAFTAR PUSTAKA}

Hartono, \& Gregorius Chandra. (2005). Service Quality and Satisfaction. Yogyakarta: Penerbit Andi.

Parasuraman, A., Valarie, A. Z., \& Leonard L, B. (1988). SERVQUAL- A Multiple-Item Scale for Measuring Consumer Perceptions of Service Quality. Journal of Retailing, 64(1), 12-37.

Priambodo, E. B. (2009). Analisis Dimensi Service Quality Penerimaan Pajak Bumi dan Bangunan (service quality) yang Dipertimbangkan dan Mempengaruhi Kepuasan Wajib Pajak (Peningkatan Pendapatan) Dinas Pendapatan Pengelolaan Keuangan dan Asset Daerah di Kabupaten Ponorogo. Thesis Tidak Dipublikasikan. Program Pasca Sarjana. Universitas Brawijaya Malang.

Pujiastuti. (2009). Faktor- Faktor yang Mempengaruhi Dimensi Service Quality Penerimaan Pajak Bumi dan Bangunan (Service Quality) Dari Kepuasan Wajib Pajak (Peningkatan Pendapatan). Thesis Tidak Dipublikasikan. Program Pasca Sarjana. Universitas Brawijaya Malang.

Singarimbun, M., \& Effendi, S. (2005). Metode Penelitian Survai. Jakarta: LP3ES.

Siu, N. Y. M., \& Cheung, J. T.-H. (2001). A Measure of Retail Service Quality. Marketing Intelligence \& Planning, 19(2), 88-96. http://doi.org/10.1108/02634500110385327

Tjiptono, F. (2005). Manajemen Bisnis. Yogyakarta: Penerbit Andi.

Tribus, E. K., \& Klassen, K. (2000). Improving Service Quality: A Study of Parking Satisfaction at a University Campus. In 12th Annual CSU-POM Faculty Development Conference. Sacramento, California.

Zeithalm, V., \& Bitner, M. J. (2002). Service Marketing (3rd ed.). McGraw-Hill Education. 